\title{
Pengaruh fenomena "sell in may and go away" terhadap imbal hasil dan resiko sektor saham di bursa efek indonesia
}

\author{
Oleh: \\ Safira Amalia Hapsari \\ Program Studi Magister Ilmu Manajemen, Fakultas Ekonomi \& Bisnis Universitas Padjajaran \\ email: sframalia@gmail.com
}

Sumarsono

Program Studi Magister Akuntansi Fakultas Ekonomi Universitas Kristen Maranatha email: ssumarsono70@yahoo.com

\begin{abstract}
ABSTRAK
Pasar saham mengenal adanya anomali, salah satunya adalah anomali musiman. Salah satu jenis anomali musiman adalah fenomena 'Sell in May and Go Away', yaitu pada waktu pasar saham sedang bearish di bulan Mei sampai dengan Oktober, investor akan menjual equity portfolio yang dimilikinya pada bulan Mei dan akan berpindah investasi pada risk free asset sampai dengan bulan Oktober. Pada bulan November sampai dengan April, pasar saham sedang mengalami bullish, pada rentang waktu bulan tersebut investor akan berpindah kembali investasinya ke equity portfolio untuk memperoleh keuntungan saat pasar sedang bullish. Penelitian ini bertujuan untuk mengetahui pengaruh fenomena 'Sell in May and Go Away' terhadap imbal hasil dan resiko sektor saham di Bursa Efek Indonesia dengan menggunakan data indeks sektor saham harian dari bulan Mei 2013 sampai bulan Mei 2018 di Bursa Efek Indonesia. Penelitian ini menggunakan data indeks sektor saham harian bulan Mei 2013 sampai dengan Mei 2018 di Bursa Efek Indonesia setelah disesuaikan. Hasil penelitian menunjukkan bahwa fenomena Sell in May and Go Away berpengaruh pada imbal hasil negative pada seluruh sektor dan yang signifikan terdapat pada sektor tertentu yaitu sektor saham pertanian dan sektor lain-lain. Sedangkan pengaruh fenomena Sell in May and Go Away ditemukan tidak signifikan terhadap resiko.
\end{abstract}

Kata kunci: "Sell in May and Go Away", Imbal Hasil, Resiko

\begin{abstract}
The stock market recognizes anomalies, one of them is seasonal anomalies. One type of seasonal anomaly is the 'Sell in May and Go Away' phenomenon, that is when the stock market is bearish from May to October, investors will sell their equity portfolio in May and move their investment to risk-free assets until October. From November to April, the stock market is experiencing bullish. In the span of the month investors will switch their investments back to equity portfolios to gain profits when the market is bullish. This study aims to determine the effect of the phenomenon of 'Sell in May and Go Away' on returns and risks in the stock sectors on the Indonesia Stock Exchange by using daily sector stock index data from May 2013 to May 2018 on the Indonesia Stock Exchange after adjustment. Our findings show that 'Sell in May and Go Away' category had a negative effect on the return of all stock sectors and were statistically significant only on several sectors, there are Agricultural stock sector and Other Stock sectors. Meanwhile, 'Sell in May and Go Away' affect insignificantly towards risk. category had a positive or negatif effect on the risk of certain stock sectors, but there was no statistically significant.
\end{abstract}


JAFTA - Vol 2 Nomor 2, Februari (2021)

\section{Keywords: "Sell in May and Go Away", Return, Risks}

\section{PENDAHULUAN}

Investasi adalah komitmen sejumlah dana atau sumber daya lainnya yang dilakukan pada saat ini dengan tujuan memperoleh sejumlah keuntungan dimasa mendatang. Seorang investor membeli sejumlah saham saat ini dengan harapan memperoleh keuntungan dari kenaikan harga saham ataupun sejumlah dividen di masa yang akan datang sebagai imbalan atas waktu dan resiko yang terkait dengan investasi tersebut (Tandelilin, 2010).

Supaya investasi dapat menghasilkan kinerja yang optimal dibutuhkan manajemen investasi yang baik yang meliputi lima langkah aktivitas sebagai berikut: menetapkan sasaran investasi, membuat kebijakan investasi, memilih strategi portofolio, memilih aktiva/asset serta mengukur dan mengevaluasi kinerja (Fabozi, 1995).

Proses pembuatan kebijakan investasi dimulai dengan adanya keputusan alokasi terhadap jenis investasi yang ada dan proses strategi portfolio. Proses alokasi terhadap jenis investasi dan strategi portfolio yang dipilih dapat memperhatikan adanya fenomena 'Sell in May and Go Away' yang merupakan peristiwa anomali kalender yang terjadi pada bulan Mei sampai dengan Oktober setiap tahunnya. 'Sell in May and Go Away' merupakan fenomena 110 pada waktu investor menjual portofolio ekuitas mereka pada bulan Mei untuk berpindah investasi dalam aset bebas risiko sampai dengan bulan Oktober, dan kemudian berpindah kembali ke investasi portfolio ekuitas, investor akan dapat memperoleh abnormal return dari pasar bullish yang secara historis terjadi antara bulan November dan April dan menghindari pasar bearish yang biasanya terjadi antara bulan Mei dan Oktober (Santos, 2013).

Penelitian ini bertujuan untuk mengetahui pengaruh fenomena 'Sell in May and Go Away' terhadap imbal hasil dan resiko pada sektor saham di Bursa Efek Indonesia. Penelitian sebelumnnya terkait dengan fenomena 'Sell in May and Go Away' yang Pasar Modal di Indonesia juga menjadi salah satu samplingnya, seperti dilakukan oleh Zhang (2013), Andrade et al. (2013), Bouman dan Jacobsen (2002), Lloyd et al. (2017), Dumitri et al. (2011) serta Jacobsen dan Zhang (2014) telah menemukan bukti empiris terhadap pengaruh fenomena terhadap imbal hasil saham. Terkait dengan resiko, penelitian masih terbatas seperti dilakukan oleh Bouman dan Jacobsen (2002) serta Jacobsen dan Zhang (2014) yang hasilnya masih kontradiktif. Perbedaan penelitian ini dengan penelitian sebelumnya adalah pada data yang dipergunakan, penelitian ini 
mempergunakan Indeks Harga Saham Sektoral, sedangkan penelitian sebelumnnya mempergunakan data Indeks Harga Saham Gabungan.

\section{TINJAUAN PUSTAKA}

\section{Hipotesis Pasar Efisien}

Konsep pasar efisien menyiratkan adanya suatu proses penyesuaian harga sekuritas menuju keseimbangan baru sebagai respons atas informasi baru yang masuk ke pasar (Tandelilin, 2010). Pasar yang efisien adalah pasar dimana harga semua saham yang diperdagangkan telah mencerminkan semua informasi yang tersedia, sehingga dapat dirumuskan bahwa hipotesis pasar efisien adalah pasar yang efisien dimana harga saham terevaluasi dengan cepat oleh informasi penting yang berkaitan dengan saham tersebut (Tandelilin, 2010). Hipotesis ini bertumpu pada dua landasan yaitu setiap perusahaan yang terdaftar di bursa efek diamati dengan cermat oleh manajer investasi yang profesional dan harga saham ditentukan oleh keseimbangan penawaran dan permintaan saham (Mankiw, 2007)

Fama (1970) dalam Bodie et al. (2011) mengklasifikasikan bentuk pasar yang efisien ke dalam tiga efficient market hypothesis $(\mathrm{EMH})$ yaitu efisien dalam bentuk lemah (weak form), efisien dalam bentuk setengah kuat (semi strong) dan efisiensi dalam bentuk kuat (strong form).
Ketiga jenis efficient market hypothesis (EMH) dapat digambarkan dalam gambar I.

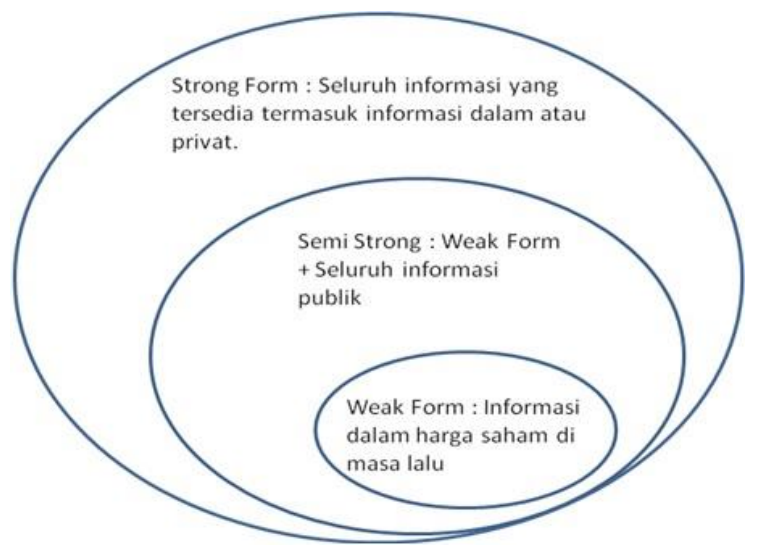

Gambar 1. Klasifikasi Efficient Market Hypothesis (EMH)

Sumber: Tandelilin (2010) dimodifikasi penulis

Efisiensi pasar dalam bentuk lemah (weak form) berarti semua informasi di masa lalu akan tercermin dalam harga yang terbentuk sekarang. Oleh karena itu harga masa lampau tersebut tidak dapat lagi dipergunakan untuk memperkirakan perubahan dimasa mendatang karena sudah tercermin pada harga masa sekarang. Akibatnya adalah investor tidak akan dapat memperkirakan nilai pasar saham dimasa mendatang dengan mempergunakan data masa lampau (Bodie et al., 2011)

Efisiensi pasar dalam bentuk setengah kuat (semi strong) berarti harga pasar yang terbentuk sekarang telah mencerminkan informasi masa lampau ditambah dengan semua informasi yang dipublikasikan. Pada pasar efisien bentuk setengah kuat, upnormal return hanya terjadi di seputar pengumuman suatu peristiwa sebagai representasi dari respons 
pasar terhadap pengumuman tersebut. Suatu pasar dinyatakan efisien dalam bentuk setengah kuat bila informasi terserap atau direspons dengan cepat oleh pasar. Upnormal return yang terjadi berkepanjangan mencerminkan sebagian respon pasar terlambat dalam menyerap atau menginterpretasi informasi dan dengan demikian dianggap pasar tidak efisien dalam bentuk setengah kuat (Bodie et al., 2011).

Efisiensi pasar dalam bentuk kuat (strong form) berarti pasar saham yang terbentuk sekarang telah mencerminkan informasi masa lampau ditambah informasi yang dipublikasikan ditambah informasi yang tidak dipublikasikan. Pada pasar efisien bentuk kuat tidak akan ada seorang investor pun yang dapat memperoleh upnormal return (Bodie et al., 2011).

\section{Fenomena "Sell in May and Go Away"}

Dalam konsep hipotesis pasar efisien, investor tidak akan dapat memperoleh abnormal return dari strategi perdagangannya. Uji statistik menunjukkan bahwa harga saham bergerak secara random walk, atau setidaknya mendekati random walk (Mankiw, 2007). Namun dalam kenyataannya investor juga irasional, banyak pergerakan harga saham tidak dikaitkan dengan informasi, investor tidak terlalu memfokuskan perhatiannya pada fundamental perusahaan dan lebih terfokus pada ekspektasi mereka terhadap investor lain yang akan membayar terhadap saham yang dipegangnya (Mankiw, 2007). Irasional tersebut menciptakan anomalianomali yang bertentangan dengan hipotesis pasar efisien, sehingga investor dapat memperoleh abnormal return melalui strategi perdagangannya. Levy dan Post (2005) membagi anomali pasar modal menjadi empat yaitu: anomali perusahaan, anomali akuntansi, anomali peristiwa dan anomali kalender.

Salah satu jenis anomali kalender adalah fenomena 'Sell in May and Go Away' yang merupakan peristiwa anomali kalender yang terjadi pada bulan Mei sampai dengan Oktober setiap tahunnya. 'Sell in May and Go Away' merupakan fenomena pada waktu investor menjual portofolio ekuitas pada bulan Mei untuk berpindah investasi dalam aset bebas risiko sampai dengan bulan Oktober, dan kemudian berpindah kembali ke investasi portfolio ekuitas, sehingga dengan investor dapat memperoleh abnormal return dari pasar bullish yang secara historis terjadi antara bulan November dan April dan menghindari pasar bearish yang biasanya terjadi antara bulan Mei dan Oktober (Santos, 2013). Disamping itu, terkait dengan siklus musiman, Bouman dan Jacobsen (2002) dalam Santos (2013) membagi kalender keuangan bulan musim panas (Mei sampai dengan Oktober) dan bulan musim dingin (November sampai dengan April). Investor menyimpan 
portofolio saham selama masa musim dingin (November sampai dengan April), dan menjualnya pada bulan Mei pada waktu mulai musim panas dan berinvestasi di pasar uang sepanjang periode musim panas tersebut (Mei sampai dengan Oktober).

\section{Hubungan Fenomena Sell in May and Go} Away Terhadap imbal Hasil

Upaya pembuktian adanya fenomena 'Sell in May and Go Away' dilakukan penelitian di pasar modal berbagai negara terhadap imbal hasil saham sebagai berikut:

1. Bouman dan Jacobsen (2002) dalam Santos (2013), mereka menemukan bukti empiris adanya efek dari fenomena 'Sell in May and Go Away' yang berpengaruhi negatif terhadap imbal hasil indeks saham pada 36 Morgan Stanley Capital International (MSCI) Index dari total 37 MSCI Index periode dari tahun 1970 sampai dengan 1998. Berarti dari MSCI Index 37 negara yang terbukti secara empiris sebanyak 36 negara.

2. Zhang (2013) meneliti fenomena 'Sell in May and Go Away' mempergunakan data dari 108 negara, termasuk Indonesia, dan terbukti secara empiris bahwa bulan Mei sampai dengan Oktober berpengaruh negatif terhadap imbal hasil saham pada 81 negara, dan yang signifikan secara statistik pada 35 negara termasuk di Indonesia.

3. Andrade et al. (2013) mengadakan penelitian fenomena 'Sell in May and Go Away' terhadap Indeks Harga Saham Gabungan 37 negara termasuk Indonesia. Data yang dipergunakan adalah data Indeks Harga Saham Gabungan mulai November 1998 sampai dengan April 2012. Hasil penelitian menemukan bukti empiris bahwa adanya pengaruh negatif imbal hasil Indeks Harga Saham Gabungan pada kurun waktu bulan Mei sampai Oktober.

4. Bouman dan Jacobsen (2002) mengadakan penelitian terhadap fenomena 'Sell in May and Go Away' dengan data indeks harga saham gabungan bulanan di negara Australia, Austria, Belgia, Kanada, Denmark, Perancis, Jerman, Hongkong, Irlandia, Italia, Jepang, Belanda, Norwegia, Singapura, Afrika Selatan, Spanyol, Swiss, Inggris, dan Amerika Serikat dan return saham di negara-negara berkembang seperti Argentina, Brazil, Chili, Finlandia, Yunani, Indonesia, Jordania, Korea, Malaysia, Meksiko, Selandia Baru, Filipina, Portugal, Rusia, Taiwan, Thailand, dan Turki. Data secara umum dari Januari 1970 sampai Agustus 1998, sedangkan di negaranegara berkembang karena keterbatasan 
data diambil mulai dari tahun 1988. Hasil penelitian menunjukkan bahwa terbukti fenomena 'Sell in May and Go Away' berpengaruh negatif terhadap imbal hasil Indeks Harga Saham Gabungan.

5. Lloyd et al. (2017) melakukan penelitian fenomena 'Sell in May and Go Away' di 35 negara, termasuk Indonesia, dengan data dari Mei 2007 sampai dengan Oktober 2015. Hasil penelitian menunjukkan bukti empiris bahwa fenomena 'Sell in May and Go Away' berpengaruh negatif terhadap imbal hasil saham di 34 negara, termasuk Indonesia.

6. Dumitri et al. (2011) melakukan penelitian fenomena 'Sell in May Go Away' di 28 negara termasuk Indonesia dengan data Januari 2000 sampai Desember 2006 dan Januari 2007 sampai dengan Desember 2011. Hasil penelitian menunjukkan bahwa fenomena 'Sell in May and Go Away' berpengaruh negatif terhadap imbal hasil indeks harga saham gabungan pada periode Januari 2000 sampai dengan Desember 2006 dan tidak berpengaruh pada imbal hasil indeks harga saham gabungan di Bursa Efek Yunani pada periode Januari 2007 sampai dengan Desember 2011.

7. Jacobsen dan Zhang (2014) melakukan penelitian fenomena 'Sell in May and Go Away' di pasar saham di 109 negara termasuk Indonesia. Hasil penelitian menunjukkan bahwa fenomena 'Sell in May and Go Away' berpengaruh negatif terhadap imbal hasil saham di 81 negara.

8. Zhao (2013) melakukan penelitian fenomena 'Sell in May and Go Away' di pasar saham 70 negara yang terdiri dari 24 negara maju, 21 negara berkembang dan 25 negara frontier, Indonesia termasuk dalam objek penelitian. Data dari tahun 1991 sampai 2013. Hasil penelitian menunjukkan bahwa fenomena 'Sell in May and Go Away' berpengaruh negatif terhadap imbal hasil saham terutama di negara-negara berkembang.

9. Guo (2014) meneliti fenomena Sell in May and Go Away pada 13 sektor industri yang ada di China yaitu teknologi informasi, industri kebudayaan, barang konsumsi, transportasi, tambang, agrikultur, retail, manufaktur, real estate, konstruksi, hidroelektrik, industri konglomerat, dan keuangan. Hasil penelitian menunjukkan bahwa pada periode bulan Mei hingga Oktober memiliki rata-rata return yang lebih kecil dibandingkan bulan lainnya dan return memiliki nilai rata-rata return negatif pada 12 dari 13 industri yang diuji. Pengaruh Sell in May and Go Away memiliki efek lemah pada industri kebudayaan, real estate, dan keuangan dan memiliki pengaruh yang 
signifikan pada industri hidroelektrik, transportasi, dan manufaktur.

10. Jacobsen (2006) menemukan bahwa kinerja return di seluruh sektor memiliki return lebih tinggi pada periode musim dingin atau bulan November - April. Sektor yang mendapat pengaruh kuat dari Sell in May and Go Away adalah sektor yang bersifat prosiklikal dan terkit dengan sektor bahan mentah dan produksi seperti sektor konstruksi, baja, dan mesin. Sedangkan sektor yang bersifat konsumsi langsung untuk konsumen dan memiliki umur produk yang pendek seperti makanan, barang konsumsi, dan keperluan tidak terpengaruh oleh Sell in May and Go Away.

Berdasarkan uraian landasan teori dan hasil penelitian tersebut diatas, maka dapat dirumuskan hipotesis pertama sebagai berikut:

$\mathrm{H}_{1}$ : Fenomena 'Sell in May and Go Away' berpengaruh negatif terhadap Imbal hasil Indeks Harga Saham Sektoral di Bursa Efek Indonesia.

\section{Hubungan Fenomena Sell in May and Go} Away dan Resiko

Dalam aktivitas investasi, selain memperoleh imbal hasil, terdapat faktor resiko yang menyertai. Hasil penelitian yang menunjukkan pengaruh fenomena
'Sell in May and Go Away' terhadap resiko adalah sebagai berikut:

1. Bouman dan Jacobsen (2002) mengadakan penelitian terhadap fenomena 'Sell in May and Go Away' dengan data indeks harga saham gabungan bulanan di negara Australia, Austria, Belgia, Kanada, Denmark, Perancis, Jerman, Hongkong, Irlandia, Italia, Jepang, Belanda, Norwegia, Singapura, Afrika Selatan, Spanyol, Swiss, Inggris, dan Amerika Serikat dan return saham di negara-negara berkembang seperti Argentina, Brazil, Chili, Finlandia, Yunani, Indonesia, Jordania, Korea, Malaysia, Meksiko, Selandia Baru, Filipina, Portugal, Rusia, Taiwan, Thailand, dan Turki. Data secara umum dari bulan Januari 1970 sampai Agustus 1998, sedangkan di negara-negara berkembang karena keterbatasan data diambil mulai dari tahun 1988. Hasil penelitian menunjukkan bahwa terbukti fenomena 'Sell in May and Go Away' tidak menimbulkan perbedaan resiko secara statistik antara kurun waktu Mei sampai dengan Oktober dengan kurun waktu November sampai dengan April, dengan demikian dapat disimpulkan fenomena 'Sell in May and Go Away' tidak berpengaruh terhadap resiko.

2. Jacobsen dan Zhang (2014) melakukan penelitian fenomena 'Sell in May and Go 
Away' di pasar saham di 109 negara termasuk Indonesia. Hasil penelitian menunjukkan bahwa fenomena 'Sell in May and Go Away' berpengaruh positif terhadap peningkatan resiko.

Memperhatikan hasil penelitian tersebut diatas menunjukkan hasil yang berbeda, kesimpulan Bouman dan Jacobsen (2002) menunjukkan 'Sell in May and Go Away' tidak berpengaruh terhadap resiko, sedangkan Jacobsen dan Zhang (2014) berpengaruh positif terhadap peningkatan resiko. Penelitian lain yang dilaksanakan oleh Jacobsen dan Zhang (2013) di pasar saham di Inggris selama 300 tahun menemukan bukti empiris bahwa ada peningkatan resiko pada kurun waktu Mei sampai dengan Oktober. Memperhatikan landasan teori dan hasil-hasil penelitian tersebut, maka dapat dirumuskan hipotesis kedua sebagai berikut:

$\mathrm{H}_{2}$ : Fenomena 'Sell in May and Go Away' berpengaruh positif terhadap Resiko Indeks Harga Saham Sektoral di Bursa Efek Indonesia.

\section{METODOLOGI PENELITIAN}

\section{Data}

Penelitian ini mempergunakan data indeks harga saham sektoral harian setelah penyesuaian di Bursa Efek Indonesia mulai bulan Mei 2013 sampai dengan April 2018. Indeks harga saham sektoral tersebut terdiri dari indeks sektor saham Pertanian, sektor
Pertambangan, sektor Industri Dasar dan Kimia, sektor Aneka Industri, sektor Industri Barang Konsumsi, sektor Property dan Real Estate serta Kontruksi Bangunan, sektor Infrastruktur dan Utility serta Transportasi, sektor Keuangan, sektor Perdagangan dan Jasa serta Investasi dan terakhir sektor lainlain.

Bulan-bulan yang masuk katagori 'Sell in May and Go Away' adalah bulan Mei sampai dengan Oktober setiap tahunnya.

\section{Definisi Operasi dan Pengukuran Variabel}

1. Imbal hasil Indeks Harga Saham Sektoral (r)

Imbal hasil Indeks Harga Saham Sektoral (r) diproksikan oleh perubahan Indeks Harga Saham Sektoral setelah adjustment di Bursa Efek Indonesia ratarata bulanan (periode) t. Pengukuran variabel dengan formulasi:

$\mathrm{r} t=(\mathrm{r} t-\mathrm{r} t-1) / \mathrm{r}-1)$

2. Resiko Indeks Harga Saham Sektoral diproksikan oleh standar deviasi harian Indeks Harga Saham Sektoral di bulan yang bersangkutan. Pengukuran variabel dengan formulasi:

$$
S=\sqrt{\frac{\sum_{i=1}^{n}\left(X_{i}-\bar{X}\right)^{2}}{n}}
$$

3. Fenomena 'Sell in May and Go Away' adalah bulan Mei sampai dengan 
Oktober yang direpresentasikan dengan dummy.

\section{Model Pengujian Hipotesis}

Pengujian hipotesis menggunakan anaisis regresi. Untuk pengujian hipotesis pertama memakai model yang dirumuskan oleh Bouman dan Jacobsen (2002) sebagai berikut:

$$
\mathrm{r}=\mu+\alpha_{1} \mathrm{St}_{\mathrm{t}}+\varepsilon \mathrm{\varepsilon t}_{\mathrm{t}}
$$

Dimana:

$\mathrm{r}_{\mathrm{t}}$ : Imbal hasil Indeks Harga Saham Sektoral pada periode $\mathrm{t}$

$\mu$ : Konstanta

$\mathrm{S}_{\mathrm{t}}$ : Dummy, nilai 1 untuk bulan-bulan Mei sampai Oktober dan nilai 0 diluar bulanbulan tersebut pada periode $\mathrm{t}$

$\varepsilon t: \quad$ Error term

Untuk pengujian hipotesis kedua memakai modifikasi model persamaan 3 sebagai berikut:

$$
\sigma_{\mathrm{t}}=\mu+\alpha_{1} \mathrm{~S}_{\mathrm{t}}+\varepsilon_{\mathrm{t}}
$$

Dimana $\sigma t$ adalah standar deviasi Indeks Harga Saham Sektoral harian pada waktu t, sedangkan penjelasan variabel lainnya sama dengan persamaan 3 .

\section{HASIL DAN PEMBAHASAN}

\section{Deskripsi Trend, Imbal Hasil dan Resiko Indeks Harga Saham Sektoral Periode Penelitian}

Trend indeks harga saham sektoral harian setelah penyesuaian di Bursa Efek Indonesia mulai bulan Mei 2013 sampai dengan April 2018 tergambar dalam Grafik 1 sampai dengan III. Indeks harga saham sektoral tersebut terdiri dari indeks sektor saham Pertanian, sektor Pertambangan, sektor Industri Dasar dan Kimia, sektor Aneka Industri, sektor Industri Barang Konsumsi, sektor Property dan Real Estate serta Kontruksi Bangunan, sektor Infrastruktur dan Utility serta Transportasi, sektor Keuangan, sektor Perdagangan dan Jasa serta Investasi dan terakhir sektor LainLain.

Grafik 1. Trend Indeks Harga Saham Sektoral Maret 2013 s/d Desember 2014

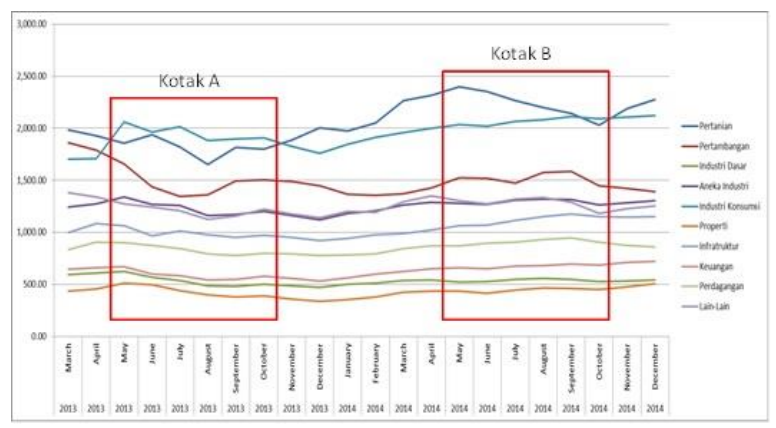

Sumber: Yahoo Finance. Penyajian secara grafik diolah oleh Penulis.

Dalam Grafik 1 digambarkan trend Indeks Harga Saham Sektoral dari Mei 2013 sampai dengan Desember 2014. Secara umum indeks harga saham sektoral berfluktuasi dengan trend mengalami kenaikan. Kotak A adalah bulan-bulan fenomena 'Sell in May and Go Away' yang 
terjadi di tahun 2013 yang menunjukkan indeks harga saham sektoral berfluktuasi dengan trend melemah. Kotak $\mathrm{B}$ adalah bulan-bulan fenomena 'Sell in May and Go Away' yang terjadi di tahun 2014 yang menunjukkan indeks harga saham sektoral secara umum berfluktuasi dengan trend melemah seperti tahun 2013, kecuali sektor Industri Barang Konsumsi, sektor Infrastruktur, Kontruksi dan Uiliti, serta sektor Keuangan.

Dalam Grafik 2 digambarkan trend Indeks Harga Saham Sektoral dari tahun 2015 sampai dengan 2016. Secara umum indeks harga saham berfluktuasi dengan trend mengalami kenaikan. Kotak A adalah bulan-bulan fenomena 'Sell in May and Go Away' yang terjadi di tahun 2015 yang menunjukkan indeks harga saham sektoral berfluktuasi dengan trend melemah. Kotak B adalah bulan-bulan fenomena 'Sell in May and Go Away' yang terjadi di tahun 2016 yang menunjukkan indeks harga saham sektoral berfluktuasi dengan trend menguat yang berbeda dengan fenomena tahun 2013, 2014 dan 2015, namun Sektor Saham LainLain memiliki trend melemah.

Grafik 2. Trend Indeks Harga Saham Sektoral Tahun 2015 s/d Desember 2016

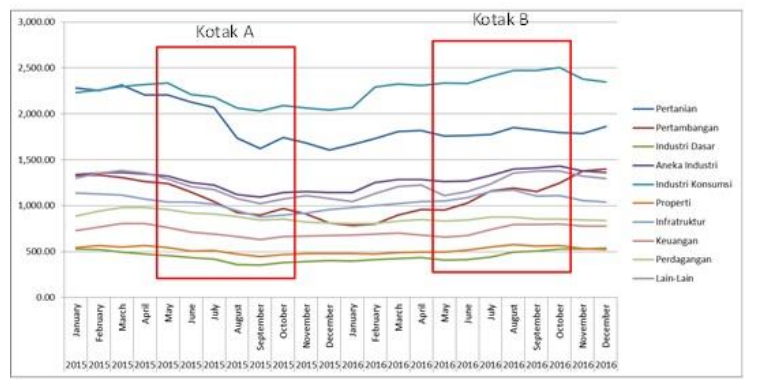

Sumber: Yahoo Finance. Penyajian secara grafik diolah oleh Penulis.

Grafik 3. Trend Indeks Harga Saham Sektoral Tahun 2017 s/d Mei 2018

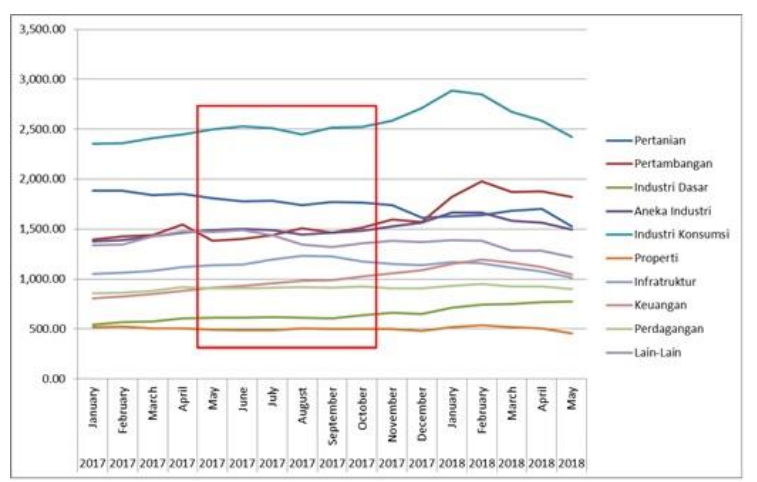

Sumber: Yahoo Finance. Penyajian secara grafik diolah oleh Penulis.

Dalam Grafik 3 digambarkan trend Indeks Harga Saham Sektoral dari tahun 2017 sampai dengan Mei 2018. Secara umum indeks harga saham berfluktuasi dengan trend mengalami kenaikan. Kotak A adalah bulan-bulan fenomena 'Sell in May and Go Away' yang terjadi di tahun 2017 yang menunjukkan secara umum indeks harga saham sektoral berfluktuasi dengan trend menguat, kecuali sektor Pertanian, sektor Properti dan Real Estate serta Kontruksi Bangunan dan sektor lain-lain.

Dalam Tabel 1 menyajikan rata-rata imbal hasil dan rata-rata standar deviasi fenomena 'Sell in May and Go Away' bulan Maret 2013 sampai dengan Mei 2018. Rata- 
rata imbal hasil indeks saham sektoral bulan Mei sampai dengan Oktober menunjukkan kinerjanya lebih rendah dibandingkan bulan November sampai dengan April. Untuk ratarata standar deviasi yang merupakan proksi dari pengukuran resiko dalam penelitian ini, dari 10 indeks sektoral, standar deviasi bulan Mei sampai dengan Oktober yang lebih tinggi dibandingkan dengan bulan November sampai dengan April sebanyak 6 sektor, sedangkan yang menunjukkan standar deviasi lebih rendah sebanyak empat sektor, yaitu sektor saham Industri Dasar dan Kimia, sektor Infrastruktur, Utiliti dan Transportasi, sektor Perdagangan, Jasa dan Investasi, serta sektor lain-lain.

Tabel 1. Rata-Rata dan Standar Deviasi Indeks Harga Saham Sektoral Fenomena 'Sell in May and Go Away' Maret 2013 s/d Mei 2018

\begin{tabular}{|c|c|c|c|c|c|}
\hline $\mathrm{Na}$ & \multirow{2}{*}{$\begin{array}{l}\text { Sektor } \\
\text { Saham }\end{array}$} & \multicolumn{2}{|c|}{ Rata-Rata Imbal Hasil } & \multicolumn{2}{|c|}{ Rata-Rata Standar Deriasi } \\
\hline & & Mei $s / d$ Okt & Nor s/d.April & Meis/d Okt & Nors/d.April \\
\hline & Pertanian & $-1.80 \%$ & $1.18 \%$ & 45.52 & 39.59 \\
\hline & Pertambang an & $-0.47 \%$ & $0.79 \%$ & 35.94 & 29.28 \\
\hline & Indus tri Dasar \& Kimia & $-0.51 \%$ & $1.60 \%$ & 13.24 & 11.77 \\
\hline & Aneka Industri & $-0.45 \%$ & $1.16 \%$ & 24.43 & 20.49 \\
\hline & Indus tri Barang Konsumsi" & $0.43 \%$ & $0.87 \%$ & 40.86 & 49.86 \\
\hline & Properti, Real Es tat \& Kontruksi Bangunan & $-0.80 \%$ & $1.17 \%$ & 12.27 & 9.70 \\
\hline & Infratrultur, Utiliti \& Transportasi" & $-0.30 \%$ & $0.46 \%$ & 18.60 & 21.01 \\
\hline 8 & Kevang an & $0.01 \%$ & $1.69 \%$ & 15.22 & 13.45 \\
\hline & Perdagangan, Jasa \& Investasi" & $-0.74 \%$ & $1.06 \%$ & 13.10 & 14.70 \\
\hline 10 & Lain-Lan" & $-139 \%$ & $1.20 \%$ & 30.71 & 31.66 \\
\hline
\end{tabular}

Sumber: Yahoo Finance. Penyajian secara grafik diolah oleh Penulis.

Keterangan: *) Rata-rata Standar Deviasi November sampai dengan April lebih besar dari pada Mei sampai dengan Oktober.

\section{Uji Asumsi Klasik}

Supaya model regresi yang dipergunakan mendapatkan hasil yang baik, maka harus memenuhi syarat best linear unbiased estimator (blue). Sehubungan regresi yang dipergunakan untuk menguji hipotesis adalah regresi sederhana, maka hanya diuji heteroskedastitas dan autokrelasi. Hasil pengujian menunjukkan bahwa model tidak mengandung heteroskedastitas dan autokrelasi tersebut.

\section{Hasil Pengujian Hipotesis}

Hasil Pengujian hipotesis satu dan dua disajikan dalam Tabel II dan III.

Tabel 2. Hasil Pengujian Hipotesis 1 Pengaruh Fenomena "Sell in May and Go Away" Terhadap Imbal Hasil Indeks Harga Saham Sektoral di Bursa Efek Indonesia

\begin{tabular}{|c|c|c|c|c|c|c|c|}
\hline \multirow{3}{*}{$\mathrm{N}$} & \multirow{3}{*}{ Sektor Saham } & \multirow{3}{*}{$\begin{array}{c}\text { Arah } \\
\text { Hipotesi }\end{array}$} & \multicolumn{4}{|c|}{ Hasil Pengujazn Hipotesis } & \multirow{3}{*}{ Keteranģan } \\
\hline & & & Arat & & & Signifikansi & \\
\hline & & & & Arah & Prob & Signifikansi & \\
\hline & Pertanian & - & -2.641401 & & 0.0105 & Signifikan $=5 \%$ & Terbukti \\
\hline & Pertanb angan & - & -0.784276 & - & 0.4361 & Tid ak Signifikan & Tidak Terbukt \\
\hline & Industri Das ar \& Kimia & - & -1.618686 & - & 0.1109 & Tid ak Signitikan & Tidak Terbult \\
\hline & Anela Industi & . & -1.948935 & - & 0.0560 & Tti ak Sign nifilan & Tidak Terbukt \\
\hline & Ind usti Barang Konsu & - & 0.415981 & & 0.6789 & Td ak Signifilan & Tidak Terbukt \\
\hline & Properti, Raal Estat \& Kontrulsi Bangunan & . & -1.575923 & - & 0.3681 & Id ak Signifilan & Tid ak Terbukt \\
\hline & Infratrukttur, Utititi \& Transportas & - & -0.402426 & & 0.6888 & Tid ak Signifilan & Tidak Terbukt \\
\hline & Kevangan & . & -1.198977 & - & 0.2354 & Tó ak Signifikan & Tidak Terbukt \\
\hline & Perdagangan, J & - & -1.63723 & - & 0.1070 & Tid ak Signifilan & Tidak Terbukt \\
\hline & Lain & & -2.039579 & & 0.0460 & Signifikan $=5 \%$ & Terbukti \\
\hline
\end{tabular}

Sumber: Pengolahan Data

Tabel 3. Hasil Pengujian Hipotesis 2 Pengaruh "Sell in May and Go Away" Terhadap Resiko Indeks Harga Saham Sektoral di Bursa Efek Indonesia

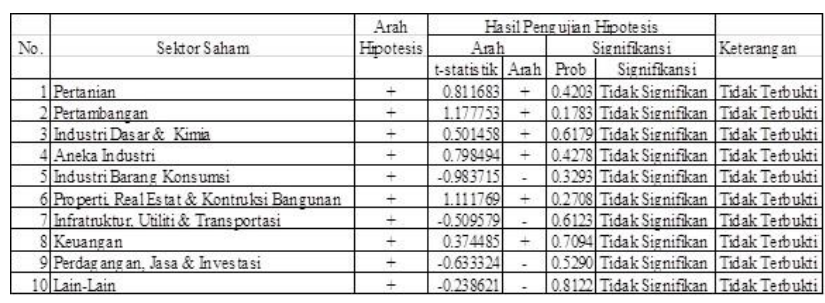

Sumber: Pengolahan Data

\section{Analisis}

Pengujian Hipotesis H1: Fenomena 'Sell in May and Go Away' berpengaruh negatif terhadap Imbal Hasil Indeks Harga Saham Sektoral di Bursa Efek Indonesia 
Berdasarkan pengujian hipotesis pertama menemukan bukti empiris bahwa fenomena 'Sell in May and Go Away' berpengaruh negatif terhadap seluruh imbal hasil Indeks Harga Saham Sektoral di Bursa Efek Indonesia dan yang signifikan secara statistik adalah pengaruh terhadap imbal hasil indeks harga saham sektor Pertanian dan sektor lain-lain.

Memperhatikan hasil pengujian hipotesis tersebut, dapat disimpulkan selain Sektor Saham Pertanian dan Sektor Saham Lain-Lain, memiliki imbal hasil yang secara statistik tidak berbeda pada kurun waktu bulan Mei sampai dengan Oktober dan kurun waktu November sampai dengan April di setiap tahunnya, sehingga bulan November sampai dengan April tidak ada upnormal return yang disebabkan adanya fenomena 'Sell in May and Go Away'. Sedangkan untuk sektor Pertanian dan sektor lain-Lain, pada periode bulan November sampai dengan April terjadi upnormal return. Perbandingan selisih ratarata imbal hasil indeks sektor saham, menunjukkan selisih rata-rata imbal hasil bulan Mei sampai dengan Oktober dengan rata-rata imbal hasil bulan November sampai dengan April Sektor Pertanian dan sektor Lain-lain menunjukkan selisih ratarata imbal hasil yang tertinggi, sektor Pertanian sebesar 2,98\% dan sektor LainLain sebesar 2,6\%, secara detil seperti disajikan dalam Tabel 4.
Berdasarkan Grafik 1 sampai dengan 3 yang menyajikan trend indeks harga saham sektoral, pada periode bulan Mei Oktober dari tahun 2013 hingga 2015 dan tahun 2017, sektor saham Pertanian dan sektor saham Lain-lain memiliki tren kinerja yang melemah dibandingkan dengan sektor saham lainnya. Sedangkan pada tahun 2016, hanya sektor saham Lain-lain yang menunjukkan tren indeks harga yang melemah.

Berdasarkan penelaahan terhadap hasil penelitian terdahulu, hasil penelitian Zhang (2013), Andrade et al. (2013), Bouman dan Jacobsen (2002), Lloyd et al. (2017), Dumitri et al. (2011) serta Jacobsen dan Zhang (2014) menunjukkan fenomena 'Sell in May and Go Away' berpengaruh negatif terhadap imbal hasil di Bursa Efek Indonesia. Namun karena data yang dipergunakan dalam penelitian tersebut adalah data Indeks Harga Saham Gabungan, maka tidak dapat disimpulkan hasil penelitian ini mengkonfirmasi hasil penelitian tersebut, ditambah dari sepuluh sektor saham, hanya dua sektor yang hasilnya sama dengan penelitian tersebut, berbeda jika fenomena 'Sell in May and Go Away' berpengaruh negatif terhadap imbal hasil dari kesepuluh sektor saham yang ada. 
Tabel 4. Selisih Rata-rata Imbal Hasil Akibat Fenomena "Sell in May and Go Away"

\begin{tabular}{|c|c|c|c|c|}
\hline \multirow{2}{*}{ No. } & \multirow[t]{2}{*}{ Sektor } & \multicolumn{3}{|c|}{ Rata-Rata Imbal Hasil } \\
\hline & & Mei s/d Okt & Nor s/d April & Selisih \\
\hline 1 & Pertanian & $-1.80 \%$ & $1.18 \%$ & $2.98 \%$ \\
\hline 2 & Pertambangan & $-0.47 \%$ & $0.79 \%$ & $1.26 \%$ \\
\hline 3 & Industri Dasar \& Kimia & $-0.51 \%$ & $1.60 \%$ & $2.11 \%$ \\
\hline 4 & Aneka Industri & $-0.45 \%$ & $1.16 \%$ & $1.61 \%$ \\
\hline 5 & Industri Barang Konsumsi & $0.43 \%$ & $0.87 \%$ & $0.44 \%$ \\
\hline 6 & Properti, RealEstat \& Kontruksi Bangman & $-0.80 \%$ & $1.17 \%$ & $1.97 \%$ \\
\hline 7 & Irfratruktur, Utiliti \& Transportasi & $-0.30 \%$ & $0.46 \%$ & $0.75 \%$ \\
\hline 8 & Keurngan & $0.01 \%$ & $1.69 \%$ & $1.68 \%$ \\
\hline 9 & Perdagangan Jasa \& Investas & $-0.74 \%$ & $1.06 \%$ & $1.80 \%$ \\
\hline 10 & Lain-Lain & $-1.39 \%$ & $1.20 \%$ & $2.60 \%$ \\
\hline
\end{tabular}

Sumber: Yahoo Finance. Penyajian secara grafik diolah oleh Penulis.

Memperhatikan hasil temuan penelitian ini serta hasil penelitian peneliti terdahulu dapat disimpulkan bahwa fenomena 'Sell in May and Go Away' tidak mempengaruhi keseluruhan imbal hasil sektor saham di Bursa Indonesia. Jika fenomena 'Sell in May and Go Away' dikaitkan dengan siklus musiman seperti yang disampaikan oleh Bouman dan Jacobsen (2002) dalam Santos (2013) yang membagi kalender keuangan bulan musim panas (Mei sampai dengan Oktober) dan bulan musim dingin (November sampai dengan April) dan investor menyimpan portofolio saham selama masa musim dingin, dan menjualnya pada bulan Mei pada waktu awal mulai musim panas dan berinvestasi di pasar uang sepanjang periode musim panas, fenomena tersebut tidak sesuai dengan musim di Indonesia yang tidak memiliki dikotonomi musim panas dan dingin, sehingga tidak mempengaruhi perilaku investasi berdasarkan musiman di negara yang memiliki dua musim. Sektor
Saham Pertanian memiliki kinerja lebih rendah di bulan Mei sampai dengan Oktober dimungkinkan karena sebagian besar wilayah Indonesia di bulan-bulan tersebut masuk pada musim kemarau sehingga mempengaruhi kinerja keuangan emiten sektor pertanian yang akhirnya mempengaruhi harga saham sektor tersebut.

Pengujian Hipotesis Hz: Fenomena 'Sell in May and Go Away' berpengaruh positif terhadap Resiko Indeks Harga Saham

\section{Sektoral di Bursa Efek Indonesia}

Berdasarkan pengujian hipotesis kedua menemukan bukti empiris bahwa fenomena 'Sell in May and Go Away' berpengaruh tidak signifikan terhadap resiko seluruh Indeks Harga Saham Sektoral di Bursa Efek Indonesia.

Fenomena 'Sell in May and Go Away' yang berpengaruh positif terhadap resiko terjadi pada Sektor Saham Pertanian, Sektor Saham Pertambangan, Sektor saham Industri Dasar dan Kimia, Sektor Saham Aneka Industri, Sektor Saham Properti, Real Estate dan Kontruksi Bangunan serta Sektor Saham Keuangan, dan berpengaruh negative pada Sektor Saham Industri Barang Konsumsi, Sektor Saham Infrastruktur, Utiliti dan Transportasi, Sektor Saham Perdagangan, Jasa dan Investasi serta Sektor Saham Lain-Lain. Memperhatikan isi Tabel I, fenomena 'Sell in May and Go Away' pada periode yang diuji yaitu tahun 2013 hingga 
2018 memiliki pengaruh positif terhadap resiko sektor saham dengan rata-rata standar deviasi lebih tinggi di bulan Mei sampai dengan Oktober dibandingkan dengan bulan November sampai dengan April. Sedangkan yang memiliki pengaruh negatif terhadap sektor saham, rata-sara standar deviasinya di bulan Mei sampai dengan Oktober lebih rendah dibandingkan dengan standar deviasi bulan November sampai dengan April. Namun karena secara statistik tidak signifikan, maka tidak ada perbedaan resiko antara bulan Mei sampai dengan Oktober dan kurun waktu antara November sampai dengan April di setiap tahunnya

Hasil pengujian hipotesis penelitian ini mengkonfirmasi hasil penelitian Bouman dan Jacobsen (2002) yang mengadakan penelitian terhadap fenomena 'Sell in May and Go Away' di berbagai negara termasuk Indonesia. Hasil penelitian menunjukkan fenomena 'Sell in May and Go Away' tidak menimbulkan perbedaan resiko secara statistik kurun waktu Mei sampai dengan Oktober dengan kurun waktu November sampai dengan April. Namun hasil pengujian hipotesis penelitian ini berbeda dengan hasil penelitian Jacobsen dan and Zhang (2014) yang melakukan penelitian fenomena 'Sell in May and Go Away' di pasar saham di 109 negara termasuk Indonesia. Hasil penelitian menunjukkan bahwa fenomena 'Sell in May and Go Away' berpengaruh positif terhadap peningkatan resiko. Perbedaan hasil penelitian tersebut dapat dimungkinkan karena adanya perbedaan jenis data yang dipakai dan kurun waktu penelitian yang tidak sama.

Memperhatikan hasil temuan penelitian ini serta hasil penelitian peneliti terdahulu, jika fenomena 'Sell in May and Go Away' dikaitkan dengan siklus musiman seperti yang disampaikan oleh Bouman dan Jacobsen (2002) dalam Santos (2013), dimungkinkan karena Indonesia tidak mengenal dikotonomi dua musim, sehingga fenomena 'Sell in May and Go Away' tidak berpengaruh terhadap resiko di Bursa Efek Indonesia.

\section{KESIMPULAN DAN SARAN}

Berdasarkan pengujian hipotesis menunjukkan bahwa fenomena 'Sell in May and Go Away' hanya berpengaruh negatif signifikan terhadap imbal hasil sektor tertentu yaitu saham sektor pertanian dan sektor lain-lain. Sedangkan pengaruhnya terhadap resiko, fenomena 'Sell in May and Go Away' berpengaruh tidak signifikan terhadap resiko seluruh Indeks Harga Saham Sektoral di Bursa Efek Indonesia.

Berdasarkan kesimpulan tersebut diatas maka dapat maka direkomendasikan hal-hal sebagai berikut :

1. Untuk Akademisi, dapat mengembangkan penelitian ini dengan pemakaian proksi yang berbeda untuk 
pengukuran imbal hasil, resiko, perpanjangan jangka waktu penelitian dan penambahan variabel independen lainnya.

2. Untuk Investor, hasil penelitian ini dapat dipergunakan sebagai salah satu determinan pengambilan keputusan investasi dan strategi portofolio di pasar modal dengan memperhatikan sektor saham sesuai dengan kurun waktu yang termasuk dalam fenomena 'Sell in May and Go Away'.

\section{DAFTAR PUSTAKA}

Andrade, S.C., Chhaochharia, V., dan Fuerst, M.E. 2013. Sell in May and Go Away" Just Won't Go Away", Financial Analysts Journal CFA Institute 2013, Volume 69, Number 4. http: //moya.bus.miami.edu/ sandrade/an drade_chhaochharia_fuerst_FAJ201 3.pdf. Diakses tanggal 11 Juli 2018. Bouman, S. dan Jacobsen, B. 2002. The Halloween Indicator, "Sell in May and Go Away" : Another Puzzle, The American Economic Review, December 2002. http://www.emergingmarketsillustra ted.com/wpcontent/uploads/2013/04/Halloween Indicator.pdf. Diakses tanggal 11 Juli 2018.
Bodie, Z., Kane, A., dan Marcus, A. J. 2011. Investment and Portfolio Management, McGraw-Hill/Irwin, New York.

Dumitriu, R., Stefanescu, R., dan Nistor, C. 2011. The Halloween Effect During Quiet and Turbulent Times, MPRA Paper No.

41539. https://mpra.ub.unimuenchen.de/41539/1/MPRA_pape r_41539.pdf. Diakses tanggal 12 Juli 2018.

Fabozi, F.J. 1995. Manajemen Investasi. Terjemahan. Salemba Empat. Jakarta.

Guo, Biao. 2014. Sell in May and Go Away: Evidence from China. Finance Research Letters. https://doi.org/10.1016/j.frl.2014.10 .001. Diakses tanggal 14 Januari 2021.

Jacobsen, B. 2006. The Halloween Effect in US Sectors. The Financial Review https://ssrn.com/abstract=901088.

Diakses tanggal 14 Januari 2021.

Jacobsen, B. dan Zhang, C.Y. 2013. Are Monthly Seasonals Real? A Three Century Perspective, Review of Finance, 2013. http://wwwstat.wharton.upenn.edu/ steele/Cou rses/434/434Context/Calendar\%20E ffects/. Diakses tanggal 12 Juli 2018. 
2014. The

Halloween Indicator, "Sell in May and Go Away": an even bigger puzzle.

https://www.tias.edu/docs/default-

source/Kennisartikelen/ssrnid2154873.pdf?sfvrsn=2. $\quad$ Diakses tanggal 11 Juli 2018.

Lloyd, R., Zhang, C., dan Rydin, S. 2017. The Halloween Indicator is More a Treat that a Trick, Journal of Accounting and Finance Volume 17 (6) $2017 . \quad$ http://www.nabusinesspress.com/JAF/JAF176/LloydR_17_6_pdf. Diakses tanggal 12 Juli 2018.

Levy, H. dan Post, T. 2005. Investment. South-Western College Publishing. Pearson Education Limited Edinburgh Gate Harlow Essex CM20 2JE England and Associated Companies.

Lloyd, R., Zhang, C., dan Rydin, S. 2017. The Halloween Indicator is More a Treat that a Trick, Journal of Accounting and Finance Volume 17 (6) $2017 . \quad$ http://www.nabusinesspress.com/JAF/JAF176/LloydR_17_6_.pdf. Diakses tanggal 12 Juli 2018.

Mankiw, N.G. 2007. Makroekonomi, Terjemahan. Edisi Keenam, Penerbit Erlangga, Jakarta.
Santos, A.M.D. 2013. "Sell in May and Go Away" Adage or Self-Fulfilling Prophecy? (Thesis). https://repositorio.ucp.pt/bitstream/1 0400.14/13831/1/MSC\%20thesis_S ell\%20in\%20May\%2. Diakses tanggal 11 Juli 2018.

Tandelilin, E. 2010. Portofolio dan Investasi, Teori dan Aplikasi, Edisi Pertama, Penerbit Kanisius, Yogyakarta.

Webiste Yahoo Finance : http://yahoo.finance.com.

Zhang, Y. 2013. An Investigation on Stock Market Calendar Month Anomalies (Thesis).

https://mro.massey.ac.nz/bitstream/ handle/10179/4768/02_whole.pdf.

Diakses tanggal 12 Juli 2018.

Zhao, R. 2013. Sell in May and Go Away Effect: Evidence from Developed, Emerging, and Frontier Markets (Thesis).

https://etd.auburn.edu/bitstream/han dle/10415/3898/Thesis_Ruwei\%20 Zhao.pdf?sequence $=$ Diakses tanggal 11 Juli 2018. 